\title{
Fiji's economy: the challenge of the future
}

\author{
Ardeshir Sepehri and A Haroon Akram-Lodhi
}

\section{Introduction}

Following a decade of relatively high rates of economic growth during the 1970s, Fiji's economic performance declined considerably in the 1980s. Economic growth both slowed down and became increasingly erratic, and for many policymakers it appeared that the country's decade-old experience with an inward-looking import-substituting industrialisation strategy had reached its limits. In an effort to restore economic growth Fiji embarked upon an orthodox structural adjustment program which sought, among other things, to redirect industrial policy towards export-led growth while pursuing macroeconomic stabilisation, external trade liberalisation and internal deregulation, including changes in agricultural markets, public sector restructuring and financial sector reform (Akram-Lodhi 1996; Elek, Hill and Tabor 1993). While the adjustment program was apparently successful, to the extent that it reversed the decline in the trend rate of growth of output, diversified exports and restored macroeconomic balances, it fell short of policymakers' expectations in other aspects. The adjustment program did little to reverse the declining trend in the rate of growth of investment, failed to achieve a reasonably high rate of growth of output, and did little to spur a generalised increase in job creation.

While Fiji's economic difficulties and their causes have been studied, these studies have been mainly descriptive; no recent attempt has been made to quantify the main constraints upon economic 
growth in Fiji. This chapter addresses this shortcoming. It assesses the role and significance of domestic private and public sector savings, as well as foreign savings, on the growth path of output by formulating and estimating a simple structural three-gap model of growth similar to that suggested by Bacha (1990) and Taylor (1991). According to the three-gap model, the utilisation and growth of productive capacity is constrained not only by domestic and foreign savings, as was initially discussed by Chenery and Strout (1966) in the context of the two-gap model, but also by the availability of public sector resources. There can be little doubt that public sector resources have played a crucial role in the economy of independent Fiji. Public sector savings and investment have been vital in determining the productive capacity of the economy and its growth rate, both directly through public enterprises and indirectly through investment in physical, social and human infrastructure. Therefore, this chapter estimates a three-gap model for the period 1971-96. The estimation results are then used to conduct simulations of the period 1997-2001. Four distinctive policy simulations are conducted. These simulations assess the impact of a gradual elimination of Fiji's preferential access to the European Union (EU) for its sugar exports as well as the amount of foreign resources that would be needed if Fiji were to achieve a socially desirable growth rate.

\section{The economy of Fiji, 1970-98}

Table 4.1 provides a summary of the major macroeconomic indicators during four main periods: the first post-independence decade, 1971 to 1981; the crisis period of 1982 to 1986; the adjustment period under the Interim Government (1989-92) ${ }^{1}$; and the most recent period of 1993 to 1996. In what follows, developments in the main macroeconomic indicators, and the underlying policy changes surrounding such developments, are examined.

\section{Economic policy and performance, 1970-812}

Fiji inherited a colonial economic structure which changed little in the decade after independence in 1970, as the government pursued a development strategy based upon seeking to secure full employment through the continued use of the country's natural resources. Thus, as in the pre-independence period, agriculture continued to be the major 


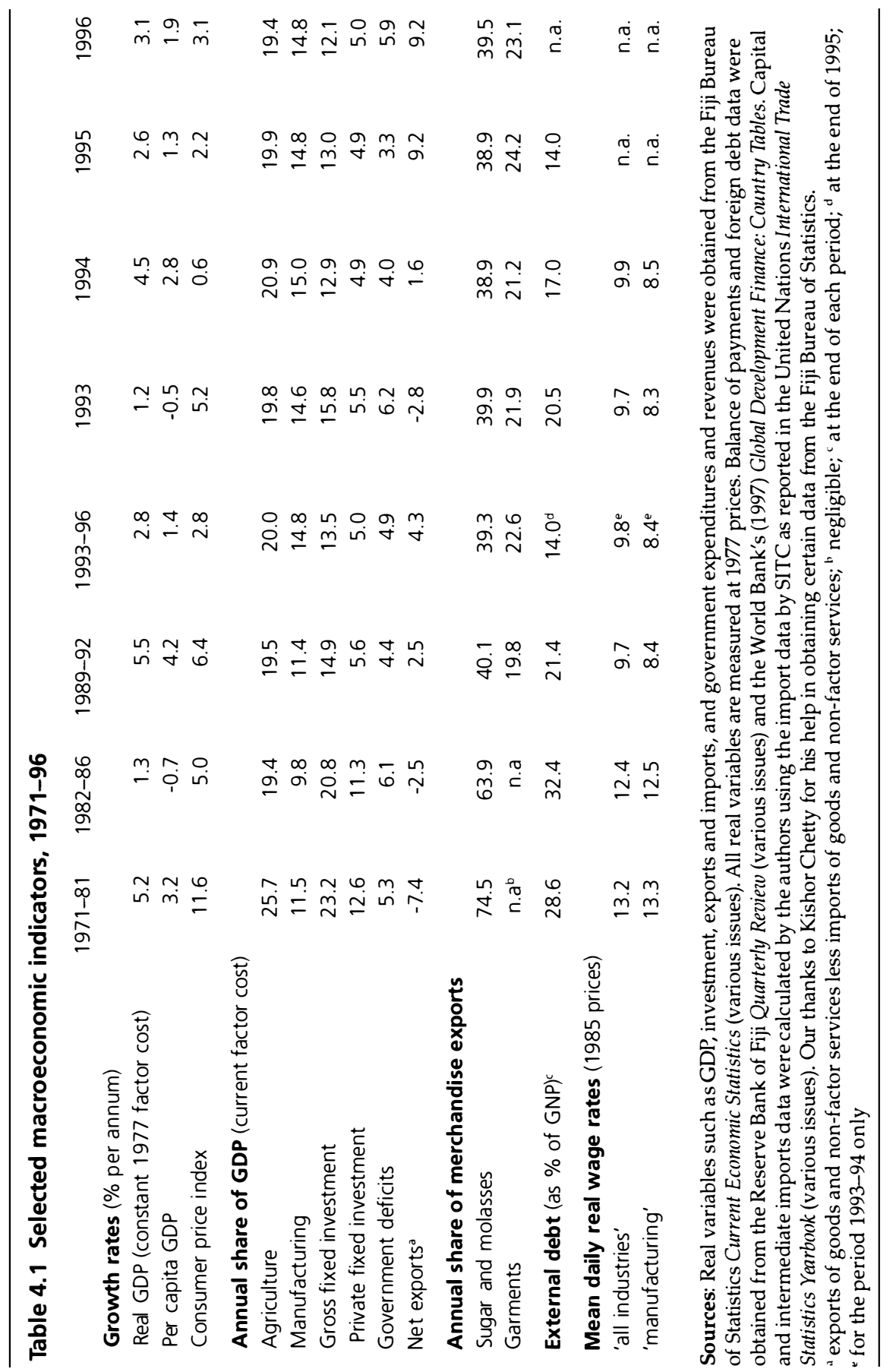


economic activity, accounting, as Table 4.1 illustrates, for over 25 per cent of gross domestic product (GDP) over the period 1971-81. Indeed, since 1970 agriculture has accounted for between 20 and 25 per cent of GDP. In 1996, agriculture provided almost a fifth of Fiji's GDP and employed, on a full-time or a part-time basis, more than 75 per cent of all households. Within agriculture, sugarcane continues to be the dominant crop. As late as 1996 sugar production accounted for over 12 per cent of GDP, more than 40 per cent of the agricultural sector, 30 per cent of the manufacturing sector, and provided direct employment for more than 25 per cent of the country's economically active population (Fiji Bureau of Statistics (various issues): Table 3.3). In 1996 the sugar industry provided about 40 per cent of exports by value (Table 4.1). Granted, the importance of the sugar sector has declined as independent Fiji has diversified its economic activities; for example, other significant natural resource-based activities currently include tourism, gold, fisheries and timber. Nonetheless, sugar production still plays a critical role in the performance of the overall economy.

In theory, Fiji's sugar industry has been subject to the dictates of the international economy. However, in practice the impact of international economic conditions on Fiji's sugar industry has been muted because of quota arrangements with the EU. The Sugar Protocol agreed between the then European Economic Community (EEC) and the Africa, Caribbean and Pacific countries came into force in 1975 under the auspices of Protocol 3 of the Lomé Convention (Prasad and Akram-Lodhi 1998). The Sugar Protocol committed Fiji to delivering specific quantities of sugar to the EEC at prices which were guaranteed and which were based upon the price of sugar set annually under the EEC's Common Agricultural Policy. In 1975 Fiji was allocated a quota of 163,600 metric tons of sugar, equivalent to 13.4 per cent of the total preferential quota. For the period 1990-92 Fiji's quota allocation amounted to an average of 42 per cent of the country's total sugar production and 46.6 per cent of the country's total sugar exports (MacDonald 1996). Fiji received a price which not only averaged between 2.5 and 3 times the world market price but which was also significantly more stable than the world market price (Hermann and Weiss 1995).

In contrast to natural resource-based economic activities, the manufacturing sector has been small in size and subordinate in terms of its economic importance. The limited industrial development that 
occurred during the first post-independence decade was largely based upon import-substitution, which protected domestic industries through a complex regulatory regime deploying quota, license and tariff protection. Thus, the contribution of manufacturing to GDP rose slightly from less than 11 per cent at the time of independence to about 13 per cent by the end of first post-independence decade. The lower priority attached to industrialisation partly reflected the widely shared view that very small economies have only a limited potential for industrialisation. It also reflected an emphasis on employmentgenerating labour-intensive activities as a means of maintaining communal relations between a population almost equally divided between indigenous Fijians and Indo-Fijians.

However, despite trade barriers the economy always had a comparatively high degree of openness to the international economy. Fiji relied upon a vast range of imported consumption, intermediate and capital goods to meet the demands of consumers and firms. Thus, in the period between 1971 and 1981, imports accounted for about 57 per cent of GDP, exports for almost half of GDP, and net exports for 7.4 per cent of GDP (Table 4.1). Post-colonial Fiji was therefore a hybrid: an economy with elements of dirigisme which was nonetheless deeply insinuated into the world economy (Narayan 1984).

State regulation was not confined to external trade. Indeed, it can be argued that the most important intervention by the government was the regulation of factor and product markets within the economy. A Prices and Incomes Board (PIB) was established to monitor and control the wholesale and retail prices of many goods and some services. In addition to the PIB, several ministries, including the present Ministries of Tourism and Transport, Works and Energy, Commerce, Business Development and Investment, Public Enterprises, and Labour and Industrial Relations, and several quasi-autonomous government institutions like the Native Land Trust Board and the Fijian Affairs Board, were empowered to regulate product and factor markets, including land and labour. The post-colonial government also exercised considerable power over productive activity, both directly, by establishing public enterprises in agriculture, manufacturing and services, as well as indirectly, by planning and setting production targets. Finally, the state intervened heavily in financial markets: interest rates were controlled, and the exchange rate was fixed. 


\section{Economic crisis, 1982-86}

Overall economic performance, as measured by the rate of growth of GDP, has varied considerably since 1970 (Table 4.1). In the first decade following independence, economic performance was generally good, as Fiji witnessed real GDP growth of 5.2 per cent per year and removed 'some of the worst elements of the colonial inheritance' (Cameron 1994:420). However, this performance was not sustained through the first half of the 1980s. In the early 1980s 'Fiji was undergoing a multi-dimensional crisis' (Cameron 1994:420) consisting of drought, cyclones, the 1979 oil price rise, and unexpected turbulence in international sugar prices. As a consequence, real GDP growth dropped to 1.2 per cent per annum during the period between 1982 and 1986; over the same period, real per capita GDP contracted by 0.7 per cent per year. As might be expected, the stagnation of output was accompanied by increasing fiscal imbalance: the fiscal deficit rose from 5.3 per cent of GDP during the period between 1971 and 1981 to 6.1 per cent during the period between 1982 to 1986 . Foreign debt also continued to grow. Foreign debt as a percentage of gross national product (GNP) rose from 28.6 per cent at the end of 1982 to 32.4 per cent by the end of 1986 (Table 4.1).

In light of what was clearly an economic crisis, in late 1986 the Finance Minister outlined the beginning of a change in Fiji's industrial policy by announcing the creation of tax-free factories, a form of export-processing zone (Akram-Lodhi 1992). This initiative was meant to be a first decisive step in a shift in industrial policy away from import-substitution and towards export promotion, a shift which had an extremely long gestation period, having been first mooted in Development Plan 6 published in 1970 (Chandra 1985). However, the 1986 shift in industrial policy became a much deeper transformation in economic strategy in the wake of two coups led by LieutenantColonel Sitiveni Rabuka in May and September 1987.

The 1987 coups were a severe economic shock. Tourism dropped by some 36 per cent, while farmers disrupted the sugar cane harvest in protest. The cessation of concessional credit, a sharp fall in inflows of foreign direct investment, and the flight of an estimated F\$120 million (US\$83 million) out of the country in 1987 and 1988 all reduced considerably the availability of foreign financial resources and hence imports. Given that some 40 per cent of budget revenues came from 
customs and excise, the impact of the coups was quickly experienced by government: between 1986 and 1987 the budget deficit increased by over 12.5 per cent, to stand at almost 8 per cent of GDP. It was partly in response to the deepening crisis that the newly-appointed, military-backed Interim Government 'pinpointed industrialisation as being of prime importance to Fiji's future development' (Chandra 1989:170) in that it could both stabilise and indeed expand the economy, and thus act to offset possible political unrest.

\section{Embedding structural adjustment, 1987-92}

In transforming economic strategy the Interim Government was not only claiming to respond to the higher costs, excess capacity and resource misallocation associated with Fiji's attempt at importsubstitution, problems initially identified in the government's review of Development Plan 7 (Fiji Ministry of Finance, Central Planning Office 1979). It was also 'responding both to the international trend towards economic liberalisation and export-oriented industrialisation and to specific advice from its consultants and international agencies' (Chandra 1989:170). This advice had argued that Fiji needed to radically improve its export potential by reducing unit labour costs if it was to continue to grow (World Bank 1986; Fiji Employment and Development Mission 1984). Given that much of this advice had been received prior to the coups, and given that the initial creation of tax-free factories predated the coups, the transformation in Fiji's economic strategy that occurred after 1987 should not so much be seen as a dramatic break with the past as rather a confirmation of policy processes which had already been initiated prior to the coups.

The central themes in Fiji's transformation of economic strategy were embedded in the formulation and implementation of an orthodox structural adjustment program that by and large shared many features of World Bank and International Monetary Fundsponsored programs. The important exception to this rule was that Fiji received no financial transfers from either multilateral institution in exchange for initiating the program. The adjustment program aimed at a far reaching economic change through macroeconomic stabilisation, external trade liberalisation and internal deregulation, including changes in agricultural markets, public sector restructuring and financial sector reforms. These policy reforms were to facilitate 
economic restructuring and transform Fiji from an 'inward looking, high tax, and slow growth economy to a dynamic outward looking, low tax and high growth economy' (Fiji Ministry of Finance 1991).

\section{Macroeconomic stabilisation}

The increase in the budget deficit brought about by the collapse in tourism and the disruption of the sugar cane harvest necessitated the stabilisation of the economy. The govermment did this by implementing deflationary fiscal and monetary policies. On the fiscal side, the government imposed a 15 per cent wage cut on all civil servants. It also slashed public investment in real terms by a third. On the monetary side, the central bank, the Reserve Bank of Fiji, severely restricted the availability of private sector credit and imposed additional restrictions on outflows of foreign exchange.

However, undoubtedly the most important component of the Interim Government's stabilisation package was a devaluation of the Fiji dollar (Akram-Lodhi 1996). The value of the Fiji dollar is fixed by the Reserve Bank relative to a weighted basket of the currencies of Fiji's principal trading partners. A two-stage devaluation in June and October 1987 reduced the value of the dollar in nominal terms by some 33 per cent. When combined with the decline in real wages the impact was to bring about a fall in the real effective exchange rate of almost 28 per cent in the period between 1986 and 1988. The effect was to reduce further the attractiveness of capital flight and improve the competitive position of the economy by reversing the decline in output and investment caused by the coups.

However, the government did not stop at stabilisation. It used economic crisis to cement macroeconomic reform by restructuring Fiji's fiscal stance. In the 1990 budget the Finance Minister felt confident enough to cut income tax rates by 20 per cent, leaving the highest rate at 40 per cent. At the same time exemptions and allowances were increased. To compensate for the loss of revenue and to ease the transition to a new value-added, tax existing indirect taxes were raised and the tax base was broadened by bringing some 40,000 peasants into income tax for the first time. Plans to 'corporatise' several state-owned enterprises also moved forward. While this effort to force state-owned enterprises to follow commercial practices was envisaged to be a prelude to privatisation, the more immediate positive impact from the government's point of view was on its own accounts. 
In the Interim Government's final 1992 budget further cuts in income tax and corporation tax were announced, the number of income tax bands was reduced, corporation tax was simplified, income tax thresholds were increased and the requirement that those below the threshold pay tax was ended. Finally, despite the resignation of the Interim Government prior to the May 1992 election, a key policy initiative, the much-debated value-added tax, was introduced on schedule in July by the newly elected government.

\section{Trade liberalisation}

The most visible aspect of the Interim Government's adjustment program was that of external trade liberalisation. Tax-free factories quickly became an important feature of Fiji's industrial and export policy (Akram-Lodhi 1992). Tax-free factories received substantial tax concessions in exchange for a commitment to export 95 per cent of output. Such concessions were available to both Fiji and international firms, thus placing both within a similar regulatory regime. Of the 119 firms engaged in tax-free manufacturing by the end of 1992, 70 per cent were in garment production. Despite the fact that garment exports had started to increase prior to the introduction of tax-free factories, the performance of the garment factories was impressive: by 1990 garment production for export comprised over 55 per cent of manufacturing production, over 22 per cent of total domestic exports, and over 37 per cent of all manufacturing employment (Akram-Lodhi 1992; Elek, Hill and Tabor 1993). Almost half of those firms operating tax-free factories in 1992 were transnational corporations, albeit from a narrow group of countries. Economic changes in Australia and New Zealand in particular forced garment producers from those countries to seek to source production offshore in countries such as Fiji. In order to attract such businesses, the Interim Government eased and simplified approval procedures for foreign direct investment while at the same time expanding the resources available to the Fiji Trade and Investment Board so that it could enhance its capacity to attract foreign direct investment. Thus, the share of foreign direct investment in GDP was 27 per cent higher under the adjustment period of 1989 to 1992 as compared to that of the immediate pre-adjustment period of 1982 to 1986 . The increase in international investment flows directed into Fiji might be taken to be a sign of confidence in the irreversible 
nature of the change in Fiji towards a liberal, export-oriented economic regime. It also indicates the extent to which trade and investment are complementary phenomena.

As regards imports, external trade liberalisation has meant an effective end to import licensing. The licensing regime used to sustain import substitution was largely eradicated as Fiji switched to an open general license scheme covering most consumption, intermediate and capital goods. Thus, prior to 1989 over 47 commodities required licenses; in 1991, only 9 commodities required licenses (Elek, Hill and Tabor 1993). The government replaced import licensing with a simplified structure of tariffs. Maximum tariff levels were progressively cut, so that by 1992 most imports had attached to them a fiscal duty of 30 per cent. Indeed, the last budget of the Interim Government held out the prospect of a maximum tariff of only 20 per cent in 1993, in part due to the introduction of a value-added tax designed to assist in reducing the dependence of revenue upon customs levies.

\section{Internal deregulation}

External trade liberalisation was accompanied by extensive internal deregulation. The overall thrust of the changes involved a reduction in barriers to entry in domestic markets, thereby potentially enhancing competitive discipline. Obviously, the shift to an open general license scheme was an important component of a reduction in barriers to entry. So too was the reduction and simplification of customs duties and corporation tax. However, internal deregulation went further than these obvious changes. Detailed sectoral economic targeting was eliminated after the coups. This reduced the non-market, linkageenhancing planning requirements that had been placed upon some firms. An enhancement of the role of markets was furthered by the elimination of price controls on a range of items. Indeed, the need for price controls was to some extent eliminated by the introduction of enforceable trading standards by the Ministry of Trade and Commerce in the last year of the Interim Government.

Barriers to market entry were further diminished by attempts at reforming state-owned enterprises. Under the auspices of the Public Enterprise Unit in the Ministry of Finance and Economic Planning, the government corporatised several large public enterprises. This placed some state-owned enterprises on the same legal and commercial basis 
as private sector firms, with the government theoretically committed to simply acting as the majority shareholder. Corporatisation led some firms to conduct efficiency-enhancing internal reforms. At the same time, the process did in theory open up protected markets to competition. However, only one seriously unprofitable firm was closed, while industrial action in several corporatised companies resulted in the kind of government intervention that corporatisation was supposed to prevent.

The final major internal deregulation initiative of the Interim Government was to enhance the flexibility of the labour market (Chand, this volume). In 1991 statutory wage guidelines were abolished in order to strengthen the position of employers in establishing the relationship between pay and productivity. This was followed by changes to labour legislation, which substantially increased government intervention in the internal affairs of unions. The effect of these changes to labour legislation was to make it less likely that the 80 per cent of the formally employed labour force which belonged to trades unions, professional associations or other, similar, organisations would assert their right to withdraw their labour.

There can be no doubt concerning the impressive stabilisation of the economy in the period following the coups. Although real per capita GDP shrank by over 7 per cent in 1987 and inflation peaked at 12 per cent in November 1988, by mid 1988 the economy was recovering. As demonstrated in Table 4.1, the economy grew at an average annual rate of 5.5 per cent over the period between 1989 and 1992 , fiscal deficits were reduced to 4.4 per cent of GDP, and net exports turned positive for the first time. Recovery was fuelled by higher sugar export earnings and by a gradual expansion of private sector credit. The recovery of the sugar sector was accompanied by a return of tourists; thus, government revenues increased. Buoyant government revenues permitted 1987 public sector wage cuts to be restored in real terms in 1988 and 1989. At the same time, higher earnings from sugar exports and tourism, combined with higher export earnings from garment and increasing foreign direct investment, helped to raise foreign reserves and reduce foreign debt. Net foreign direct investment increased from US\$6.3 million in 1987 to an average annual net inflow of US $\$ 43$ million during the period between 1989 and 1992. 
While the structural adjustment program of 1987-92 was quite instrumental in restoring economic growth, it did little to reverse the decline in the trend rate of growth of investment, and particularly private investment. The share of fixed investment in GDP declined from 23 per cent during the period 1971-82 to just under 15 per cent during the period 1989-92 (Table 4.1). Indeed, it dropped to as low as 12.1 per cent in 1996. Private investment as a percentage of GDP almost halved, dropping from its peak value of 14 per cent during the period 1977-81 to 7.4 per cent during the period 1987-92. The economic crisis of the early 1980s, combined with fiscal restraints during the adjustment period, growing uncertainty over property rights in land and the future direction of government policy reforms, put severe constraints upon the growth of investment.

\section{Economic policy under Rabuka, 1993-98}

In 1992 elections were held under the provisions of the discriminatory 1990 Constitution. Rabuka, the leader of the coups and now a Major General, became Prime Minister at the head of a Soqosoqo Ni Vakavulewa Ni Taukei-General Voters' Party coalition government. Under Rabuka's leadership the explicit commitment to structural adjustment did not change: economic policy remained committed to macroeconomic stabilisation, external trade liberalisation and internal trade deregulation. Nonetheless, the exigencies of electoral politicshowever flawed - meant that the context had certainly shifted. While policy reform continued, the pace of reform slowed. Moreover, the impact of fluctuating fortunes in the sugar and tourism sectors sustained continued efforts by the govemment to diversify the pattern of economic activity, especially through the encouragement of manufacturing.

Between 1993 and 1996 the economy grew at an annual average rate of 2.8 per cent-much less than that achieved in the decade following independence (Table 4.1). As they had since the mid 1980s, sugar, garment manufacturing and tourism dominated economic performance between 1993 and 1996. Sugar was responsible for 42 per cent of agricultural production in 1996. Moreover, between 1993 and 1996 sugar comprised over 39 per cent of total exports (Table 4.1). At the same time, the redirection of industrial strategy towards exportled growth in the mid 1980s led to a steady increase in manufacturing's contribution to GDP. By 1996 manufacturing accounted for almost 15 per cent of GDP (Table 4.1). While sugar 
remained responsible for 22.4 per cent of manufacturing production in 1996 , the sector was in fact dominated by garment production for export in 120 tax-free factories, which in 1997 were responsible for two-thirds of all manufacturing employment. Garment exports increased from 4.1 per cent of total exports in 1986 to 23.1 per cent of total exports in 1996. Indeed, the efforts of successive governments to transform Fiji into an export-oriented economy were, by the late 1990s, clearly successful. Exports went from 16.2 per cent of GDP in 1985 to 28.2 per cent of GDP in 1994. Sugar and garments between them were responsible for over 60 per cent of all merchandise exports in 1996, and well over 60,000 jobs (Table 4.1). Tourism, which provided around 20 per cent of GDP in 1996, also made an important contribution to net exports. The steady improvement in trade balances during the early 1990s led net exports, which had been in deficit for most of the postcolonial period, to move into surplus. The improvement in the trade balances helped to restore foreign reserves-which in 1997 stood at US $\$ 347$ million - and reduce foreign debt. Total foreign debt dropped from an average of 21.4 per cent of GNP in 1992 period to 14 per cent in 1995 (Table 4.1). Inflation, which in Fiji is mainly determined by import prices and the exchange rate, was also significantly cut, averaging 2.8 per cent between 1993 and 1996.

However, the public finances of low growth, export-driven Fiji were not particularly strong between 1993 and 1996 (Table 4.1). The government ran consistent budget deficits, which over the period between 1993 and 1996 averaged 4.9 per cent of GDP. Moreover, while the public finances did begin to improve in 1994 and 1995 (Table 4.1), it was subsequently discovered that the state-owned National Bank of Fiji (NBF), the largest domestic commercial bank, had, as a consequence of financial mismanagement and possible corruption, accumulated bad debts of more than $\mathrm{F} \$ 200$ million (US $\$ 143$ million) and was near to collapse. In order to restructure the NBF the government was forced to give it a $\mathrm{F} \$ 213.3$ million (US $\$ 152$ million) injection of capital. The impact of the rescue of the NBF on the budget deficit was enormous: the budget deficit reached an unsustainable 9.2 per cent of GDP in 1997, of which over 12.3 per cent was a direct result of the rescue.

At the same time, consistent budget deficits had other, less contingent, causes. A first factor was that the government had to meet accumulated debt repayment obligations. In 1996 accumulated debt 
repayments accounted for 16 per cent of government spending and over the period between 1993 and 1996 debt repayments often exceeded the size of the budget deficit. Nonetheless, the strength of exports implied that the debt burden, while heavy, was manageable: the debt-service ratio fell from 11.2 per cent in 1991 to 5.9 per cent in 1995.

A second factor was that the government was continuing to restructure its tools of revenue acquisition. In order to boost domestic competitiveness, the government sought to reform pricing in water, power and telecommunications utilities. In order to boost international competitiveness, increase simplicity and transparency, and in order to comply with World Trade Organization (WTO) nondiscretionary policies, the 1998 budget reviewed the tariff structure. Tariffs were cut on many imported non-locally produced goods. Some 97 non-locally produced goods were subjected to a new tariff of 10 per cent, while some goods were moved onto a zero-tariff band. For those imported goods that competed with locally produced goods, tariffs were increased to 35 per cent. However, such a tariff fell within the WTO bound rate of 40 per cent. Moreover, it was promised that tariffs for imported goods that competed with locally produced goods would fall by 3 per cent a year every year to 2002 .

Fiscal weakness also contributed to budgetary deficits.

Privatisation proceeds had been expected during the 1990s to improve the public finances. However, the first privatisation attempted by the government, that of the Government Shipyard, was a mess. One of the partners in the buyout went into receivership and government had to spend time and money searching for a new partner. At the same time, attempts to speed up privatisation required large budgetary outlays in order to meet the initial expenses of reorganising corporatised stateowned enterprises and in order to locate possible purchasers of the assets.

Fiscal weakness was exacerbated by tax non-compliance. The Finance Minister in the 1998 budget estimated that some 13 per cent of government revenues were lost due to non-compliance. In part, noncompliance may have been a result of corruption as, in addition to the NBF scandal, in 1997 the police had launched corruption probes into the Customs Department, the Companies Office, the RegistrarGeneral's Department and the Fiji Housing Authority. There can be little doubt that the perception that corruption in Fiji was becoming 
both wider and deeper was at least in part responsible for the Finance Minister's 1998 decision to set up an autonomous and independent Fiji Revenue and Customs Authority.

Within the context of a low growth, export-driven, fiscally weak economy, the government relied heavily upon monetary policy. Between 1993 and 1996 the Reserve Bank allowed the M1 measure of the money supply to grow at an annual average rate of 11 per cent, well above both the nominal rate of growth of the economy and the real interest rate, in order to encourage growth. In order to offset the pressure on the exchange rate caused by monetary expansion, in 1997 the government relaxed foreign exchange controls in an effort to increase inflows of foreign direct investment. However, in order to relax foreign exchange controls, the process of liberalising the current account was begun. While this had the affect of delegating current account transactions to commercial banks and increasing the share of retained export proceeds, it also had the affect of increasing the size of permissible company profit remittances and easing the capacity to invest offshore, both of which served to put further pressure on the exchange rate.

However, unlike 1988, when an easing of monetary policy contributed to expansion, monetary policy failed to sustain an increase in the rate of growth of output. The government could not sustain the unsustainable, and in January 1998 the most important shift in monetary policy of the decade occurred when the Reserve Bank devalued the Fiji dollar by 20 per cent. Ostensibly, the basis of the decision to devalue was the need to mount a defensive reaction to the East Asian crisis, which had led to substantial depreciations in Thailand, Malaysia, Indonesia, South Korea and the Philippines. In the wake of these depreciations, Fiji's two largest trading partners, Australia and New Zealand, had seen their currencies depreciate. In Fiji's low growth, import-dependent, export-driven economy, the relative appreciation of the Fiji dollar against the currencies of the country's two largest trading partners meant a loss of competitiveness and a reduced capacity to export. This had the potential to dramatically destabilise the economy. At the same time, movements in the gold price had worked against the economy.

Nonetheless, it is clear that devaluation in and of itself will not resolve the weaknesses of the Fiji economy in the short and medium term. It is true that devaluation will boost domestic production, as 
locally produced products become cheaper than imports with which they compete. However, the scope for import-substitution in Fiji's small, open economy is clearly limited. Both exports and imports are very insensitive to changes in relative prices: price elasticities of the demand for exports and imports are estimated to be as low as -0.44 and -0.27 respectively (Reddy 1997: Tables 1 and 2). Fiji's import dependence must severely restrict the benefits of devaluation. Consider, for example, the three principal export industries. Sugar earnings from exports in Fiji dollar terms will rise as a result of the devaluation. However, so too will the cost of essential production and processing inputs that have to be imported, as well as the cost of transport. Similarly, devaluation might make the Fiji tourist industry more competitive. However, the sector as a whole is highly import dependent (Korth, this volume), and devaluation has raised the price of imports. The net benefits are thus likely to be much smaller than anticipated by policy makers. Finally, while the garment industry will have been given a competitive boost by the devaluation, the fact that labour is the only domestically provided input in the industry would serve to offset the competitive boost. Moreover, in those sectors where Fiji competes directly with East Asian countries and companies, the devaluation is, in many instances, less than the depreciation of their currencies, meaning that Fiji after the devaluation has lost a competitive advantage. This applies particularly to garments and tourism.

At the same time, with increases in the prices of imports, inflation will rise in the short term and consumers will have to bear the brunt of the increase. The decline in real wages arising out of increased inflation should mean that the devaluation would impact upon domestic demand. Thus, it is clear that devaluation is an unimaginative means of dealing with a stagnant economy. The need to devalue also makes clear that after more than a decade of structural adjustment, the economy of Fiji is still plagued by structural weaknesses. That this is recognised by policymakers is clear from comments on the imperatives facing the Fiji economy in the wake of devaluation: govemment stressed the need for producers to reduce unit labour costs by improving efficiency and cutting costs. There are two routes by which lower labour costs could be secured in Fiji. The first is by cutting real wages; however, as already noted, cuts in real wages would serve to restrict domestic demand and economic growth. The second is by increasing investment and hence 
labour productivity; however, the prospect for an improvement in productivity remains poor as long as the share of investment in GDP continues to fall, in the manner illustrated in Table 4.1.

Although per capita income grew at an average annual rate of 4.2 and 1.4 per cent during the periods 1989-92 and 1993-96 respectively, the benefits of growth were not equitably distributed. It is estimated that 25 per cent of Fiji's households in general and 32.8 per cent of urban households in particular lived in poverty in 1990. Moreover, the proportion of the population in poverty between 1977 and 1990 increased by about 10 percentage points amongst households overall, and by 21 percentage points amongst urban households (Prasad and Asafu-Adjaye 1998). According to the United Nations Development Programme, this situation had deteriorated by 1996, especially as a result of rapid food price rises, rises which will accelerate in the wake of the 1998 devaluation (United Nations Development Programme/ Government of Fiji 1997). Other indicators of income inequality, such as the Gini coefficient, also show a worsening of income distribution. The estimated Gini coefficient for Fiji suggests that, nationally, income inequality deteriorated by about 10 percentage points between 1990 and 1997 for households overall, and by as much as 19 percentage points for urban households (Prasad and Asafu-Adjaye 1998).

Moreover, as illustrated in Table 4.1, mean daily real wages in 'all industries' declined from an average of $\mathrm{F} \$ 12.40$ during the period $1982-86$ to $\mathrm{F} \$ 9.70$ during the period 1989-92. The decline in real wages was consistent over the entire period between 1982 and 1992. It was more pronounced in the manufacturing sector, where mean daily real wages declined from an average of $\mathrm{F} \$ 12.52$ in the period 1982-86 to an average of $F \$ 8.40$ in the period 1993-94, a decline of 33 per cent. Stagnant real wages sit alongside poor employment prospects for many. By the year 2000, 11,000 annual entrants onto the labour market will be chasing 5,000 annually created new jobs. Clearly, the current situation is a recipe for social conflict that can only be averted by jobcreating, demand-enhancing investment.

Yet, as Table 4.1 indicates, investment continued its trend decline between 1993 and 1996, dropping to as low as 12.1 per cent of GDP in 1996. The government, in the wake of low levels of investment, has explicitly sought to increase foreign direct investment, usually through the deployment of tax concessions. This is especially so in the tax-free factories, where 120 factories are responsible for two-thirds of all 
manufacturing employment and 23 per cent of exports. However, the impact of the tax-free factories on the Fiji economy is reduced by leakages: half of all garment exports go to Australia, but non-labour inputs into garment production come from Australia. The result is that for some garment exports Australian content may reach 67 per cent of the product's value. Net exports from garments are therefore low. Fiji has been seeking revisions to the South Pacific Regional Trade and Economic Cooperation Agreement's (SPARTECA) rules of origin, which dictate 50 per cent local content. It has long been realised that the rules of origin discourage efficiency improvements by discouraging investment (Akram-Lodhi 1992).

Tax concessions have also been used to little effect in the tourist industry. The government's most recent policy package was designed to increase the stock of five-star hotels in the country. To that end, investors were offered a 20-year corporate income tax holiday, the duty free entry of all capital goods, other concessions, and the option to sell privately-generated electricity to the national grid. The impact on investment has however been limited. Tax concessions have also been used in the timber industry, but although it has became an important export earner, in producing exports oneseventh the value of those generated by sugar, it has been, to policymakers, a disappointment. The only sector where investment has been increasing has been in gold production, in which Emperor Gold Mines has expanded even as Pacific Island Gold has begun operating the new Mount Kasi mine. Gold generated 9.9 per cent of exports in 1996; however, the recent slump in the world gold price will affect further investment. Moreover, the scope for expansion is clearly limited.

The current policy of granting concessions to investors has thus proven to be ineffective in boosting investment. Moreover, it may be fiscally unsustainable. As Elek, Hill and Tabor (1993:763) observe in the context of tax concessions to the garment industry, '[i]f, as is likely, the relative share of export firms in the economy continues to expand, then it will become increasingly difficult to finance the physical infrastructure they need, or to assure an adequate supply of skill unless they make a contribution-through taxes-to the cost of providing them'. 


\section{The next decade}

The need to boost investment is also a priority because of the major challenges facing Fiji's economy in the next decade. Under the Uruguay Round's Agreement on Agriculture, the market access provisions of the Sugar Protocol were locked into the tariff schedules inspected and agreed upon by all signatories to the Agreement and subsequently all members of the WTO. The Agreement did not however make specific provisions in favour of Fiji. This means that the main continued benefit of the Protocol lies in its quota allocations and the price it offers for Fiji's sugar. However, it is likely that after 1999 there will be major downward pressure on the EU's internal sugar price, and thus the price received by Fiji for its sugar, as a result of two factors. The first is the reform of the EU's Common Agricultural Policy, which is becoming increasingly likely. The second is the next round of WTO-initiated multilateral trade negotiations in agricultural products, which under the terms of the Agreement on Agriculture are due to begin in 1999. These negotiations 'will set in train a more powerful impetus to change than may at first sight seem obvious' (Roberts 1996:6). Negotiations

can be expected to broadly follow the lines of the Uruguay Round: further reductions of support, increases in market access (e.g. through further reduction of tariffs and tariff equivalents) and further reduction in export subsidies and subsidised export quantities (Roberts 1996:5).

Downward pressures on the sugar price received by Fiji will only be reinforced if, in the negotiations to construct a successor arrangement to the Lomé Convention, negotiations that commenced in 1998, Article 24 of the General Agreement on Tariffs and Trade is more strictly interpreted. A stricter interpretation is probable, in an effort to achieve WTO consistency. The implication of Article 24 is that the successor arrangement would have to move towards free trade over a specified time period and include all significant economic sectors, including sugar (Prasad and Akram-Lodhi 1998). If such were to be the case, the Sugar Protocol would become redundant, and would, in all probability, be scrapped, an outcome which would represent a severe economic shock to Fiji. 
In addition, it is likely that SPARTECA will be revised over the course of the next decade, in part because Fiji has been seeking a bilateral agreement with Australia which strengthens its access to the dominant economy in the region, and in part because Australia has been considering enhancing its trade-based assistance. However, new agreements might not be as beneficial as might be thought. Australia and Fiji are both members of the WTO and thus agreements covering their trading relationships must be consistent with the rules of the WTO, and in particular Article 24. This implies that any revised agreements would have, as a final outcome, free trade over a specified time period, which would exclude no significant economic sector. It is difficult to envisage the circumstances under which an economy as small as Fiji's could avoid the trade-reducing impact of Australia's absolute advantage.

\section{A three-gap model ${ }^{3}$}

Domestic investment, foreign resources and government resources have all played a major part in Fiji's economic performance since independence. Clearly, economic performance has, in the aggregate, not been good, especially in the 1990s. Thus, the low growth, exportdriven, fiscally weak, import-dependent economy of Fiji faces major challenges over the medium term. There is in particular an urgent need to improve the share of investment in the economy if the poor economic performance of the 1990s is not to be replicated. In order to assess the significance of the level of government resources and foreign resources, as well as domestic savings, on the growth path of output and investment in Fiji, in this section a structural three-gap model of growth along the lines suggested by Fanelli, Frenkel and Winograd (1987), Bacha (1990) and Taylor (1991) is specified and estimated.

The three-gap model provides a general framework by which to assess the role and significance of domestic private and public sector saving, as well as foreign saving, on the growth path of output and investment. At the same time, the three-gap model explicitly considers the interaction between capacity expansion and capacity utilisation. Finally, the three-gap model has minimal data requirements for both estimation and simulation. These three features make the three-gap model a more suitable means of understanding macroeconomic 
growth processes than that provided by other open economy macroeconomic models. Granted, the three-gap model is a highly aggregated one-sector growth model in which price variations, including exchange rate variations, are not explicitly incorporated. Although it is possible to incorporate absolute prices into the threegap model (Solimano 1993), it is not yet possible to incorporate relative prices. This obvious limitation of the three-gap model should however be weighed against the already-mentioned benefits of the model. At the same time, the use of the three-gap model for understanding economies under adjustment is limited by the assumption that the structure of the economy is not changing. It should be noted though that this shortcoming is not particular to the three-gap model; most open economy macroeconomic models suffer from the same shortcoming.

According to the three-gap model, the utilisation and expansion of existing productive capacity is constrained not only by domestic and foreign savings, as was initially discussed by Chenery and Strout (1966) in the context of the two-gap model, but also by the impact of fiscal limitations on government spending and thus on its public investment choices. In the absence of well-developed financial markets, the available methods of financing public investment are mostly confined to foreign borrowing, budget surpluses and inflation. Foreign resources can play a particularly significant role, especially if cutting current expenditures and inflation-based financing are not possible, either due to political circumstances or to external pressures on the fiscal authorities to curtail inflation.

The model's formulation is presented in Table 4.2. All variables in the model are defined as a percentage of potential output $(Q)$, which was estimated by passing a linear line through output peaks for the period between 1971 and 1996.

Equation 1 defines real output $(X)$ as the sum of gross domestic product (GDP) and real intermediate imports $\left(\mathrm{M}_{\mathrm{k}}\right)^{4}$ Capacity utilisation $(\mathrm{u})$ is defined by Equation 2 as a ratio of output $(\mathrm{X})$ over potential output $(\mathrm{Q})$. The rationale for working with $\mathrm{X}$ and $\mathrm{Q}$ as separate variables is that many developing economies often operate at less than full capacity, mainly as a result of the unavailability of foreign exchange and other structural bottlenecks. The capacity utilisation rate, then, allows an exploration of the way the three gaps interact in the process of economic growth. 
Table 4.2 Specification of the three-gap model

\begin{tabular}{|c|c|c|}
\hline Real output & $X=G D P+M_{k}$ & \\
\hline Capacity utilisation & $\mathrm{u}=\mathrm{X} / \mathrm{Q}$ & \\
\hline Growth rate & $g=g_{0}+k i$ & $\forall g_{0} ; k>0$ \\
\hline Equilibrium & $i=s$ & \\
\hline Total investment & $i=i_{p}+i_{g}$ & \\
\hline Total saving & $s=s_{p}+s_{g}+s_{f}$ & \\
\hline Private investment & $i_{p}=i_{0}+\alpha i_{g}+\beta u$ & $\forall a ; b>0$ \\
\hline Private saving & $\mathrm{s}_{\mathrm{p}}=\sigma_{0}+\sigma_{1} \mathrm{u}$ & $\forall \sigma_{0} ; 0<\sigma_{1}<1$ \\
\hline Public sector saving & $s_{g}=z-\zeta j^{*}$ & $0<\zeta<1$ \\
\hline Fiscal effort & $z=z_{0}+z_{1} u$ & $\forall z_{0} ; z_{1}>0$ \\
\hline Public sector borrowing & & \\
\hline requirements & $\pi u=i_{g}-s_{g}$ & \\
\hline Intermediate imports & $m_{k}=a_{0}+a_{1} u$ & $\forall a_{0} ; 0<a_{1}<1$ \\
\hline Capital goods imports & $m_{2}=m_{0}+m_{1} i$ & $\forall m_{0} ; 0<m_{1}<1$ \\
\hline Foreign saving & $s_{f}=m+m_{k}+m_{z}+$ & $=\phi=\Delta \delta+\delta g+r$ \\
\hline Three-gap equations & & \\
\hline Growth-investment equation & $\mathrm{i}_{g}=[1 /(1+\alpha)][(\bar{g}$ & $\left.-\left(i_{0}+\beta u\right)\right]$ \\
\hline Savings gap & $(1+\alpha) i_{g}-\left(\sigma_{1}+z_{1}\right.$ & $=z_{0}-\zeta j^{*}+\sigma_{0}+\phi-i_{0}$ \\
\hline Foreign exchange gap & $m_{1}(1+\alpha) i_{g}+\left[a_{1}+\right.$ & \\
\hline & $=\phi-m-j^{*}-m_{0}-$ & $b+e$ \\
\hline Fiscal gap & $i_{g}-\left(\pi+z_{1}\right) u=z_{0}$ & \\
\hline
\end{tabular}

Output growth is determined along Harrod-Domar lines, according to which the rate of growth of potential output $(\mathrm{g})$ is specified in Equation 3 as a linear function of the investment rate (i), which is in turn defined as investment as a percentage of potential output. The parameter $(\mathrm{k})$ denotes the incremental output-capital ratio, while $\left(\mathrm{g}_{\mathrm{o}}\right)$ denotes other factors affecting the rate of growth of output, such as labour productivity growth. Equation 4 states the equilibrium condition, or savings constraint, according to which investment (i) is equal to savings (s). Total investment in Equation 5 is specified as the sum of private investment $\left(i_{p}\right)$ and government 
investment $\left(\mathrm{i}_{g}\right)$, with government investment defined as excluding investment by state-owned enterprises. Equation 6 specifies total savings as consisting of private saving $\left(\mathrm{s}_{\mathrm{p}}\right)^{5}$, public sector saving $\left(\mathrm{s}_{\mathrm{g}}\right)$ and foreign saving $\left(\mathrm{s}_{\mathrm{f}}\right)$. Private investment is defined in Equation 7. It is assumed that private investment varies with changes in demand conditions, as measured by $(\mathrm{u})$, and with government investment. Private sector investment can vary positively with government investment, a 'crowding-in' effect, or negatively with government investment, a so-called 'crowding out' effect, depending on whether these two types of investment are complements or substitutes. Private savings are defined in Equation 8 and are specified in a standard way, according to which savings are assumed to vary positively with the capacity utilisation variable $(\mathrm{u})$.

Public sector savings, investment and borrowing requirements are explained by Equations 9 to 11. Public sector savings are defined in Equation 9 as the difference between the fiscal effort variable $(z)$ and interest payments on the government's foreign debt $\left(\zeta j^{*}\right)$, where $\left(j^{*}\right)$ denotes interest payments on foreign debt and $(\zeta)$ the government's share. In Equation 10 the variable ( $\mathrm{z}$ ) defines the fiscal effort rate, also known as the public sector operating surplus, as the difference between current revenue net of transfers and subsidies plus the operating surpluses of public enterprises less government consumption expenditures and interest payments on the public sector's domestic debt. According to Equation 10, the public sector operating surplus is assumed to be primarily determined by the capacity utilisation rate $(\mathrm{u})$, in that taxes, surpluses from public enterprises, and other receipts rise more rapidly than current spending when economic activity goes up. The strength of this response is measured by the parameter $\left(z_{1}\right)$, the marginal fiscal effort rate. In addition to the rate of capacity utilisation, the fiscal effort rate is influenced by other factors such as size of the tax base and the effectiveness of tax collection system. The strength of these other factors is captured by the parameter $\left(\mathrm{z}_{\mathrm{o}}\right)$. Equation 11 defines the public sector borrowing requirement $(\pi \mathrm{u})$, or the public sector saving constraint, as the difference between government investment $\left(\mathrm{i}_{\mathrm{g}}\right)$ and public sector saving $\left(\mathrm{s}_{\mathrm{g}}\right)$. Note that in Equation 11 the public sector borrowing requirement $(\pi)$ is measured as a proportion of output $(X)$, while $(\pi \mathrm{u})$ denotes the public sector borrowing requirement as a percentage of potential output $(Q)$. 
The external sector is summarised by Equations 12 to 14 . The import demand for intermediate goods $\left(m_{k}\right)$ is specified as a function of the capacity utilisation rate $(u)$ in Equation 12, while import demand for capital goods $\left(\mathrm{m}_{\mathrm{z}}\right)$ is specified as a function of domestic investment (i) in Equation 13. Equation 14 defines foreign savings, or the balance of payments constraint. The first part of Equation 14 defines the current account deficit as competitive imports $(\mathrm{m})$ plus intermediate imports $\left(m_{k}\right)$ plus capital goods imports $\left(m_{z}\right)$ plus interest payments on foreign debt $\left(j^{*}\right)$ less exports $(e)$. The capital account is presented in the second part of Equation 14, where $(\Delta \delta)$ denotes changes in the ratio of foreign debt over potential output, $(\delta g)$ changes in official reserves, $(r)$ the ratio of other capital inflows-such as foreign direct investment-over potential output, and $(\phi)$ total capital inflows as a percentage of potential output. Exports and capital inflows are treated as exogenous variables.

The growth-investment equation, the savings gap equation, the foreign exchange gap equation, and the public sector savings gap equation are obtained from Equations 1 to 14 and are presented as Equations 15 through $18 .{ }^{6}$ In Equation 15, government investment $\left(i_{g}\right)$ and the capacity utilisation rate $(\mathrm{u})$ are treated as variables which can be traded off to give macroeconomic equilibrium, meaning that the growth rate of capacity output $(\mathrm{g}$ ) can be treated as a target policy variable. While the focus of Equation 15 is on government investment and capacity utilisation and not on growth, which, as documented earlier, has been weak, treating the growth rate of capacity output as a target policy variable is clearly attractive given poor economic performance. Equation 15 thus relates government investment $\left(i_{g}\right)$ to the capacity utilisation rate $(\mathrm{u})$ and targeted potential output growth $(\bar{g})$. The savings gap Equation 16 gives the maximum government investment attainable from a given rate of capacity utilisation $(u)$ that satisfies the equilibrium condition defined in Equation 4. Higher government investment increases private investment and capacity utilisation and thereby generates sufficient savings to finance the higher investment. According to the foreign savings gap Equation 17, there is a trade off between government investment $\left(i_{g}\right)$ and the capacity utilisation rate $(\mathrm{u})$. Higher capacity utilisation generates a higher demand for intermediate imports that can only be met, given available foreign exchange, by cutting into capital goods imports and hence by lowering the growth rate of capacity. Lastly, the fiscal gap 
Equation 18 shows government investment $\left(\mathrm{i}_{\mathrm{g}}\right)$ and the capacity utilisation rate $(\mathrm{u})$ to move together as higher capacity utilisation generates more net fiscal revenue that can be channeled into capital formation.

\section{Econometric results}

The model specified in Table 4.2 was estimated using annual data for the period between 1971 and 1996 and using an ordinary least-squares technique. ${ }^{7}$ Since capacity utilisation $(u)$ is estimated separately, simultaneity does not pose any problem. The results of the estimated behavioural equations are presented in Table 4.3. However, the parameter estimates presented in Table 4.3, as well as the simulation results presented in Table 4.4, should be treated as highly tentative. The model specified in Table 4.2 is, as already noted, a highly aggregated one-sector growth model in which price variations are not explicitly incorporated. Projected growth rates are in particular very sensitive to changes in world sugar prices and the performance of Fiji's non-sugar exports. Finally, and obviously, the quality of the data can always be better.

\section{Structural equations, three-gap results and policy implications}

Considering first the private investment equation presented in Table 4.3, the estimates generated by Equation 7 suggest that both the capacity utilisation rate and government investment are statistically significant determinants of private investment, explaining altogether about 95 per cent of the variation in the private investment rate. However, the estimated coefficient of government investment suggests that higher government investment tends to crowd out private investment. It should be noted that such crowding out need not be detrimental to the economy. The impact of crowding out on the economy would depend upon the extent of crowding out, and the relative productivity of government and private investment. The results indicate that the crowding-out effect is incomplete, while the results do not convey any information about relative productivity.

The capacity utilisation variable also appears to be a statistically significant determinant of private saving, fiscal effort and intermediate imports. Thus, the greater the degree of productive activity in the economy, the greater the rate of private savings which 
can be used to finance investment, the greater the rate of government revenue collection, and the greater the rate of imports which are used as inputs in productive activity. It can be noted that the marginal fiscal effort rate is considerably smaller than that reported for other middleincome countries (Taylor 1993: Table 2.3). It can also be noted that the estimates for intermediate imports indicate a high degree of dependence on imports. Finally, the estimates for imports of capital

\section{Table 4.3 Econometric results of the structural equations and the three-gap equations $s^{\mathrm{a}, \mathrm{b}}$}

Private investment
Private saving
Fiscal effort
Import demand
intermediate goods
capital goods ${ }^{d}$

Three-gap equations

Savings gap

Fiscal gap

Foreign exchange gap

$$
\begin{array}{rlrl}
\mathrm{i}_{\mathrm{p}}= & 0.031+0.062 \mathrm{u}-0.547 \mathrm{i}_{g} & & \\
& (1.31) \quad(4.46) & (-2.32) & \mathrm{R}^{2}=0.95 \\
\mathrm{~s}_{\mathrm{p}}= & 0.011+0.17 \mathrm{u} & & \\
& (0.71)(11.08) & & \\
\mathrm{z}= & -0.084+0.117 \mathrm{u} & \mathrm{R}^{2}=0.92 \\
& (-2.33) \quad(2.88) & & \\
& & & \mathrm{R}^{2}=0.42 \\
\mathrm{~m}_{\mathrm{k}}= & -0.116+0.316 \mathrm{u} & & \\
& (-2.43) \quad(5.87) & & \\
\mathrm{m}_{\mathrm{z}}= & 0.101+0.39 \mathrm{i} & \mathrm{R}^{2}=0.72 \\
& (0.44) \quad(2.29) & \mathrm{R}^{2}=0.80
\end{array}
$$

$$
\begin{aligned}
& i_{g}=-0.381+0.495 u \\
& i_{g}=-0.127+0.183 u \\
& i_{g}=1.59-1.924 u
\end{aligned}
$$

\section{Notes:}

${ }^{a} t$-statistics are given in parentheses under the coefficients, and the coefficients of determination $\left(R^{2}\right)$ are adjusted $R^{2}$. All equations were tested and corrected for autocorrelation.

${ }^{b}$ All equations were estimated using a dummy variable representing the coup of 1987 and the period under the Interim Government, 1987 to 1992 . The dummy variable was not statistically significant in any estimated equations, and hence is not reported here. c The private investment equation was estimated using annual data for the period 1977 to 1996. Due to the high degree of correlation between private investment and potential output, the private investment equation was estimated using the level of private investment and actual output rather than their normalised ratios. Both current and lagged values of public sector investment were included in estimating the private investment equations. The lagged values were however not statistically significant, and are therefore not reported here.

${ }^{\mathrm{d}}$ Due to the high degree of correlation between capital goods and imports and potential output, the equation for capital goods imports was estimated using the level of imports and investment rather than their normalised ratios. 
goods demonstrate that the marginal propensity to import with respect to fixed capital formation is statistically significant. It is also relatively large, indicating Fiji's high degree of dependence on imported capital goods. Thus, the greater the rate of investment, the greater the extent of capital goods imports.

Using the estimated values of the parameters and the values of the exogenous variables, the model was calibrated for 1996. The resulting three-gap equations are shown in Table 4.3 and visually displayed in Figure 4.1. Figure 4.1 demonstrates a sharp trade-off between government investment-which is to say, publicly funded capacity creation-and capacity utilisation under the foreign exchange constraint. The savings constraint line is steeper than the fiscal constraint line. This indicates that the government budgetary constraints are more binding than the savings constraint as more foreign capital becomes available. In such circumstances, an attempt to raise government investment in order to stimulate economic growth will put the government in fiscal difficulties, even though savings are in principle available to finance additional investment.

The fiscal limitations on the government, as well as the crowdingout effect of government investment, should be interpreted with great care. This is because of the highly aggregated nature of the model. Nonetheless, two possible explanations for these results can be suggested. The first is more 'economistic', in that it seeks to explain why government investment crowds out private investment. The crowding-out effect of government investment might be explained, amongst other factors, by the government's low savings rate, its massive budgetary appropriations to public enterprises, ${ }^{7}$ and the preferential access to commercial credit that has been granted to public enterprises. At the same time, the government's increasing use of tax holidays to attract both domestic and foreign investment into the export sector, and most notably the garment, tourism and minerals sectors, when considered in light of a relatively small marginal fiscal effort rate, may have in fact exacerbated fiscal weakness. As a consequence, government deficits have had to be primarily financed by domestic borrowing. However, the financing of chronic government deficits by domestic borrowing has reduced private nonfinancial investment, through a process of crowding out. There is therefore a need to recognise the impact of government spending on capacity utilisation, both in its impact on investment, through the 


\section{Figure 4.1 Foreign exchange, saving and fiscal gaps}

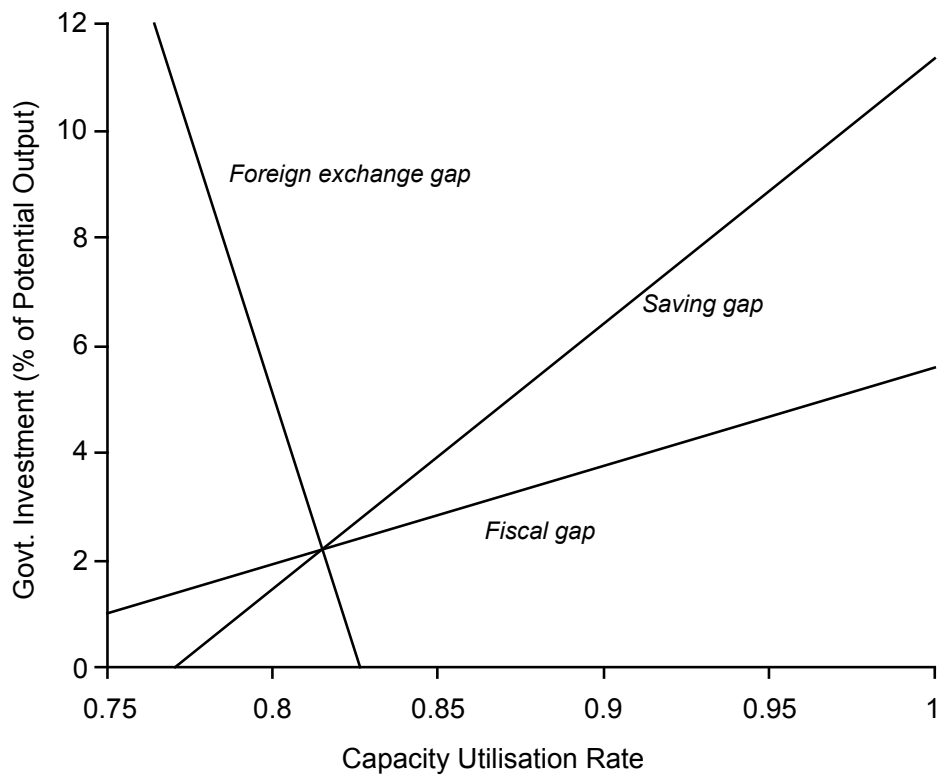

crowding-out effect, and in its generation of savings, through the inefficiency of public enterprises. In light of these possible mechanisms, it could be suggested that it is necessary to increase private domestic and foreign investment in order to enhance capacity creation and its utilisation. This in turn suggests two policies. The first deals with the monopolisation of domestic savings by the public sector, and the answer is both clear and orthodox: much deeper deregulation of the financial sector, primarily through privatisation. The second is consistent with existing government policy: the need to further mobilise external resources through the promotion of greater inflows of foreign direct investment.

However, this economistic response is not satisfactory. This is because it diagnoses symptoms without giving an understanding of underlying causes. In order to understand underlying causes, it is necessary to try and explain why there may be fiscal limitations on the government and why government intervention in capacity creation 
and utilisation may be detrimental to Fiji's economy. In order to address this broader issue, it is important to recognise that the state in Fiji through the late 1980s and 1990s has sought to establish a delicate balance between promoting private sector growth and safeguarding the interests of its principal constituency, the indigenous Fijian community (Elek, Hill and Tabor 1993). As Sutherland points out in his contribution to this volume, the pursuit of this balance has been highly contradictory. Contradictions in the pursuit of this balance may in turn have had economic consequences. Recent work on Africa has established 'strong and specific mechanisms whereby ethnically fractionalised societies were liable to have worse economic performance than more homogenous societies' (Collier 1998:12) ${ }^{8}$ This is because ethnic fragmentation may be 'bad for...macroeconomic policy, (local) government performance, public sector wage determination, and the determinants of trust' (Collier 1998:3). Granted, the negative economic implications of ethnic diversity can be overcome. Collier (1998:12) stresses that 'political institutions matter more where a society has a potential problem of ethnic fractionalisation than in homogenous societies. Democracy has the capacity almost completely to offset the economic damage which can be done by a high level of fractionalisation'. Nonetheless, ethnic diversity—and particularly, according to Collier, moderate ethnic diversity of the type experienced in Fiji-may reduce the efficiency of government in circumstances where there is a lack of political rights.

There is good reason to suspect that these kinds of mechanisms may have contributed to Fiji's economic performance during the late 1980s and 1990s. On the one hand, the state sought to maintain its political base amongst the indigenous Fijian population by reducing the political rights of the Indo-Fijian community (Sutherland, this volume; Robertson, this volume). On the other hand, the state pursued explicit and implicit policies designed to promote economic affirmative action on behalf of the indigenous Fijian community (Ratuva, this volume). These policies have expanded the scope of ethnically based patronage within the state and society, and may have given rise to rent seeking on the part of individuals. The collapse of the National Bank of Fiji illustrates the capacity for rent seeking in post-coup Fiji. Ethnic preferences in post-coup Fiji may also have contributed to other inefficiencies in the public sector. Certainly, ongoing losses in many public enterprises have been acceptable to the state, in part because of 
the 'ethnicisation' of economic policy. It is thus a reasonable hypothesis that the 'ethnicisation' of economic policy in Fiji has played a pivotal role in reducing the effectiveness of the state and has contributed to the creation of circumstances in which state intervention may be detrimental to the economy.

\section{Simulation results}

The estimated model can be used to simulate the effects of alternative policies by altering the values of individual variables such as the targeted growth rate of output, investment, exports and imports and then assessing the effect of such a change on the other variables contained in the model. In what follows, the model was simulated for the period between 1997 and 2001. These simulations were undertaken under four growth path 'scenarios'. While the first two simulations assume that Fiji's preferential access to the EU for its sugar exports will terminate by 2001, scenarios I and II differ in terms of their underlying export growth rates. Scenario I follows a rather optimistic growth path, according to which the gradual elimination of Fiji's preferential access to the EU for its sugar is matched by a corresponding and offsetting export diversification effort, as a result of which the country's export earnings remain unchanged. This rather optimistic export growth rate is adjusted under simulation II to reflect the most recent data on Fiji's non-sugar export performance and the recent slow down in the economic growth of Fiji's main trading partners.

Scenarios III and IV explore two quite different and distinctive growth paths: a growth rate that is most likely to occur; and a growth rate that meets 'socially desirable' ends. The most likely growth path scenario assumes that Fiji's preferential access to the EU remains in place until the end of 2001 and that Fiji's non-sugar export growth rate falls considerably short of those rates achieved during the early 1990s. Thus, Fiji's successful achievement in diversifying its exports during the early 1990s is assumed to come to an end. This occurs because of the low projected growth rates of Fiji's East Asian trading partners, as well as because of the domestic difficulties facing the country in its transition from the first, comparatively easy, phase of export-led growth to the next, more difficult, phase, under which the basis of such growth must be deepened in order for it to be sustained. Particular domestic issues include that of land leases (Prasad and 
Kumar, this volume), as well as the future evolution of intercommunity relations in light of the new Constitution and the 1999 general elections. By way of contrast, according to the 'socially desirable' growth path scenario, potential output and per capita output are assumed to grow at an average annual rate of 5.2 per cent and 4 per cent respectively. These rates of growth are almost identical to those rates achieved by Fiji during the 1970s. Unlike the first three scenarios, external resources are assumed to be both available and adequate under growth scenario IV, so that foreign exchange gaps, if any, can be filled. The results of these simulations are summarised in Table 4.4.

\section{Scenario I: Successful export diversification}

Considering first growth path scenario I, it is necessary to begin by noting that over the 10 year period between 1985 and 1994 Fiji received a price for its sugar exports to the EU which was, on average, 65 per cent greater than the world market price. This preferential market access provided Fiji with an implicit subsidy amounting to about 3.5 per cent of Fiji's GDP per year over the period between 1985 and 1994. The effect of a gradual elimination of this preferential market access between 1997 and 2001 on economic growth, investment, government revenues and borrowing requirements, and imports and external debt depends on the performance of non-sugar exports. For Fiji to continue to grow at the same rate as the rate of growth of output experienced in the 1996 base year-3.1 per centand with no change in savings and investment ratios and government borrowing requirements, it is projected under scenario I that nonsugar exports will have to grow at an annual average rate of 3.9 per cent between 1997 and 2001. This is noted in Table 4.4. Higher nonsugar export earnings and moderate import growth are then projected to produce a small current account surplus, equivalent to 2.5 per cent of total export earnings, and a reduction in external debt from 5.3 per cent of exports in 1996 to an average annual rate of 2.9 per cent between 1997 and 2001. However, this rate of growth of non-sugar exports appears to be unattainable, especially in light of the recent slowdown in economic growth in the East Asia and Pacific region, as well as the exhaustion of the first and easy stage of Fiji's export diversification drive. 
Table 4.4 Projected growth path scenarios, 1997-2001

\begin{tabular}{|c|c|c|c|c|c|}
\hline \multirow{2}{*}{\multicolumn{2}{|c|}{ Base year }} & \multicolumn{4}{|c|}{ Growth path scenarios } \\
\hline & & \multicolumn{2}{|c|}{ End of Sugar Protocol } & \multirow{2}{*}{ Most likely } & \multirow{2}{*}{$\begin{array}{l}\text { Socially } \\
\text { desirable }\end{array}$} \\
\hline & 1996 & $\begin{array}{c}\text { successful } \\
\text { export } \\
\text { diversification }\end{array}$ & $\begin{array}{c}\text { limited } \\
\text { export } \\
\text { diversification }\end{array}$ & & \\
\hline & & 1 & $\|$ & III & IV \\
\hline \multicolumn{6}{|l|}{$\begin{array}{l}\text { Real growth rate } \\
\text { (\% per annum) }\end{array}$} \\
\hline Actual GDP & 3.1 & 3.1 & -0.3 & 1.3 & 5.2 \\
\hline Per capita GDP & 1.9 & 1.9 & -1.5 & .1 & 4.0 \\
\hline Potential GDP & 1.3 & 3.1 & 0.9 & 0.9 & 2.0 \\
\hline Imports & 7.7 & 1.9 & -0.5 & 1.3 & 4.2 \\
\hline Exports & 15.5 & $3.9^{a}$ & $1.3^{\mathrm{a}}$ & 1.1 & 1.1 \\
\hline \multicolumn{6}{|l|}{$\begin{array}{l}\text { As } \% \text { of potential GDP } \\
\text { (period average) }\end{array}$} \\
\hline \multicolumn{6}{|l|}{ Actual output } \\
\hline (capacity utilisation rate) & 81.5 & 81.5 & 78.6 & 82.6 & 89.5 \\
\hline Fixed investment & 8.0 & 8.0 & 7.8 & 8.5 & 10.8 \\
\hline Govt. borrowing requirements & 5.4 & 5.4 & 5.4 & 5.0 & 4.7 \\
\hline \multicolumn{6}{|l|}{$\begin{array}{l}\text { As } \% \text { of exports } \\
\text { (period average) }\end{array}$} \\
\hline Imports & 97.7 & 97.7 & 98.1 & 100.6 & 107.3 \\
\hline External debt & 17.0 & 10.3 & 17.0 & 17.0 & 24.5 \\
\hline Debt services & 5.3 & 2.9 & 5.3 & 5.3 & 11.3 \\
\hline
\end{tabular}

\section{Scenario II: Limited export diversification}

In growth path scenario II, export growth rates are adjusted downward to reflect the most recent export performance of Fiji as well as the developments in East Asia. Using the latest Organisation for Economic Cooperation and Development (OECD) forecasts for Fiji's main export markets and Fiji's most recent export performance, nonsugar exports are assumed to grow at an average annual rate of only 1.3 per cent between 1997 and 2001. It is also assumed that only moderate inflows of foreign direct investment are available, there is limited access to foreign financing and there is no change in Fiji's external debt to potential output ratio between 1997 and 2001. Under these assumptions, imports and output growth will have to be 
compressed in order to make do with reduced export earnings and limited capital inflows. This compression, as reflected in the decline in output growth and the capacity utilisation rate is, as shown in Table 4.4, considerable. Reduced imports, including imports of capital and intermediate goods, make the foreign exchange constraint more binding as the gradual elimination of implicit subsidies under the Sugar Protocol pushes the foreign exchange constraint line in Figure 4.1 towards the origin. Lower export earnings also reduce the maximum achievable rate of investment. As a consequence, actual output and per capita income are projected to shrink at an average annual rate of 0.3 and 1.5 per cent respectively between 1997 and 2001. The decline in actual output combined with a slow rate of growth of potential output lowers the average rate of capacity utilisation to 78.6 per cent, and fixed investment to 7.8 per cent of potential output, over the period between 1997 and 2001. Although lower capacity utilisation reduces government tax revenues, an increase in the fiscal effort, such as the broadening of the tax base, leaves government borrowing requirements almost unchanged - the fiscal effort parameter rises from 0.117 in the base year of 1996 to 0.125 by 2001 .

\section{Scenario III: The most likely growth path}

Unlike the previous two growth path scenarios, scenario III, the most likely growth path, assumes Fiji's preferential market access will remain in place at least until the end of 2001. Making similar assumptions about the growth rates of non-sugar exports and capital inflows as those made under scenario II, the maximum achievable output and investment growth rates are reported in Table 4.4. Low rates of growth of export earnings, combined with limited capital inflows, are projected to reduce the growth rate of actual output from 3.1 per cent in 1996 to an average of 1.3 per cent per annum over the period between 1997 and 2001. With a population growth rate of about 1.2 per cent per annum, per capita income remains stagnant over the period. Fixed capital formation rises slightly, from 8 per cent of potential output in 1996 to 8.5 per cent of potential output over the period between 1997 and 2001. The small increase in fixed capital formation reflects an increase in the capacity utilisation rate from 81.5 per cent in 1996 to 82.6 per cent over the period between 1997 and 2001. This slight increase in investment is primarily brought about by an increase in government investment, which rises from 2.2 per cent of 
potential output in 1996 to 2.6 per cent of potential output over the period between 1997 and 2001. However, despite this slight increase in government investment, government borrowing requirements decline from 5.4 per cent of potential output in 1996 to 5 per cent of potential output over the period between 1997 and 2001 as additional public revenue efforts, such as a broadening of the tax base and improvements in tax collection, are achieved. Imports of capital and intermediate goods rise as a result of the increase in both capacity utilisation and fixed capital formation. These higher imports are financed partly by growing export earnings and partly by moderate capital inflows. As it has been assumed that there is limited access to foreign financing and moderate inflows of direct foreign investment, external debt and debt service as a percentage of exports remain unchanged over the period between 1997 and 2001.

\section{Scenario IV: The socially desirable growth path}

Given Fiji's low rates of economic growth during the past decade, projected economic growth under scenario III, the most likely growth path, will fall short of meeting the population's expectations and aspirations, as well the growth rates achieved by Fiji during the 1970s. Scenario IV examines the implications of a socially desirable growth path, in which actual output is assumed to grow at an average annual rate of 5.2 per cent, a rate that was achieved by Fiji in the 1970s. Potential output is also assumed to grow at annual average rate of 2 per cent. These assumptions imply a steady increase in the capacity utilisation rate over the period between 1997 and 2001, so that by 2001 capacity utilisation reaches almost 98 per cent. Higher capacity utilisation, combined with improvements in the socio-political environment, including a satisfactory resolution of land lease issues, reverse the steady decline in the investment rate experienced by Fiji during the past decade. Fixed capital formation rises from 8 per cent of potential output in 1996 to an average rate of 10.8 per cent of potential output per annum in the period between 1997 and 2001, while private investment similarly rises from 3.5 per cent of potential output in 1996 to 4.3 per cent of potential output over the period between 1997 and 2001. It should be noted that these investment rates fall considerably short of the investment rates achieved by Fiji in the 1970s, and are hence achievable. So too is the projected increase in government investment. Following years of low government 
investment and the gradual deterioration of physical infrastructure, government investment rises slightly from 2.2 per cent of potential output in 1996 to an average annual rate of 2.8 per cent over the period between 1997 and 2001. Higher government investment is partly financed by higher capacity utilisation and partly by additional public revenues - the fiscal effort parameter rises from 0.118 in 1996 to 0.125 in the period between 1997 and 2001 as the tax base is broadened and the collection of taxes is improved. As noted in Table 4.4, these higher tax revenues slightly reduce government borrowing requirements. Higher rates of capacity utilisation and investment also increase imports of capital and intermediate goods. To fill the foreign exchange gap, export earnings are supplemented by a moderate increase in foreign direct investment as well as by an increase in foreign debt. External debt is projected to grow from US $\$ 217$ million in 1996 to US $\$ 431$ million by the end of 2001; debt servicing also grows. However, relative to potential output, this foreign borrowing is not large, amounting to an average of 17.5 per cent of potential output over the period between 1997 and 2001. It is thus sustainable.

\section{The policy implications of the simulation results}

The size of the foreign financing gap under all four scenarios illustrates quite vividly the centrality of the foreign exchange constraint in general, and preferential access to the EU sugar market in particular, on the medium-term growth rate. It thus helps to explain why the Fiji government has been trying to promote and diversify exports. In the absence of compensatory financing a gradual elimination of Fiji's preferential market access will considerably reduce output growth and the capacity utilisation rate. This would have potentially destabilising consequences. For a country which has had a decade of slow growth and deepening economic insecurity, resulting, amongst other things, from the implementation of an orthodox structural adjustment program, low growth in output, investment and capacity utilisation are not without their own significant socioeconomic costs, both in the short and the long term. Moreover, given the short-term pain associated with the implementation of an orthodox structural adjustment program, these low rates of output and investment growth make it even harder to sustain the adjustment program. Finally, despite the implementation of a new constitution (Ghai, this volume), the 'ethnicisation' of 
economic policy may continue to have an effect on the growth rate. This rather bleak outcome applies not only to an extreme scenario, such as scenario II, under which Fiji's preferential market access for its sugar exports is assumed to end. It also applies, to some extent, to scenario III, under which Fiji's preferential market access is assumed to be maintained until 2001.

Clearly, if a socially desirable growth rate is to be achieved in the short and medium term, there is a need to overcome the two most binding constraints facing the Fiji economy, namely the foreign exchange constraint and the fiscal constraint. The former requires an increase in foreign capital inflows and the latter an improvement in government savings. Since increases in concessional aid for a middleincome economy such as Fiji are unlikely, the government is left with borrowing on international markets and attracting foreign direct investment in order to meet the foreign exchange requirements of a socially desirable growth path. Borrowing on the international market has its own costs, as the recent experience of East Asia clearly indicates. By way of contrast, Fiji has undoubtedly been relatively successful in attracting foreign direct investment during the adjustment period. However, the record of the adjustment period is that the government sought to attract foreign direct investment in order to 'remake' Fiji into a low-income economy. Thus, its export drive has been predicated upon attracting capital into low valueadded activities such as the low-wage, semi-skilled garment industry. This is clearly the wrong kind of export diversification, in that it is not based upon Fiji's comparative advantage. Fiji's comparative advantage surely does not lie in low value-added activities. Rather, Fiji's advantage is its workforce: well educated and comparatively well skilled. At the same time though the country is spatially isolated. The impact of spatial isolation can however be offset if Fiji uses the comparative advantage of its workforce to attract foreign direct investment into skill-intensive, higher value-added activities which are not affected by transport costs. International knowledge-based and information technology-utilising services offer one possibility which could utilise Fiji's comparatively skilled labour force and which would not necessarily be affected by Fiji's spatial isolation. Data processing is but one example of such services. Even in these circumstances though, greater care should be paid when seeking to attract international capital into Fiji. The state should seek to encourage joint ventures with 
local capital, along the lines encouraged in China, Vietnam and India, so that that technology and know-how which is transferred into the economy is predicated upon deepening the human capital available to the Fiji economy and as such building competitive advantage.

However, achieving the socially desirable path requires not only an increase in foreign capital inflows but also an improvement in government savings. This can be achieved in part by: redirecting investment, including foreign direct investment, into higher valueadded industries; by raising the fiscal effort rate and the public sector operating surplus; and by improving the efficiency of government revenue generation. Improved efficiency amongst public enterprises requires, amongst other things, greater market-based autonomy, greater managerial accountability, and a stronger link between performance and remuneration. Improvements in the productivity and operating surpluses of public enterprises would contribute to improved efficiency in government revenue generation. So too would the granting of tax concessions more wisely, the broadening of the tax base and improvements the tax collection system. Improvements in the efficiency of tax concessions requires, among other things, a shift away from the current policy of granting tax concessions across the board and towards granting them on a case-by-case basis, with the evaluation of each case based upon the extent to which the concession helps fulfil strategic priorities specified by the state.

One final point can be made. It has been hypothesised in this chapter that the 'ethnicisation' of economic policy in Fiji may have played a role in reducing the effectiveness of state intervention. Clearly, more research needs to be done on this issue. Nonetheless, if the use of ethnicity in the allocation of resources has reduced the efficiency of resource allocation by the state, there is a clear need to end the 'ethnicisation' of economic policy in Fiji.

\section{Conclusions}

The purpose of this chapter has been to review Fiji's macroeconomic performance and assess the relative significance of foreign exchange, domestic savings, and public sector resources on Fiji's economic growth. Using annual data for the period between 1971 and 1996 a three-gap model has been formulated and estimated. The estimated foreign exchange gap equation indicates a sharp trade-off between 
investment, or capacity creation, and capacity utilisation. The government savings constraint also appears to be more binding than the savings constraint as more external resources become available. In such circumstances, attempts to raise government investment in order to stimulate economic growth will put the state into fiscal difficulties even though savings are in principle available to finance additional investment.

To assess the significance for Fiji of the foreign exchange constraint in general, and Fiji's preferential access to the EU sugar market in particular, the model has been simulated for the period between 1997 and 2001 under four growth path scenarios. The first two growth path scenarios assume that Fiji's preferential market access to the EU is eliminated over the period between 1997 and 2001 but differ in their assumptions concerning the success of export diversification. The third and fourth growth path scenarios assume that Fiji's preferential market access remains in place until 2001 but differ in their assumptions concerning growth in actual output, exports and capital inflows.

The results from the first two scenarios suggest that in the absence of high growth rates of non-sugar exports, and with an absence of compensatory financing, the decline in output growth and capacity utilisation rates may be so considerable as to be potentially destabilising: the maximum achievable growth rate of per capita income was found to be -1.5 per cent per year for the period between 1997 and 2001. Even if Fiji's preferential market access were to remain in place until the end of 2001 the results of the most likely growth path scenario suggest stagnant per capita income over the period between 1997 and 2001. Given the short-term pains associated with the implementation of an orthodox structural adjustment program and the slow growth in per capita income over the past decade, these low rates of output and investment growth would make it even harder to sustain policy credibility.

However, the results suggest that the external financing required to achieve a socially desirable growth path is modest, amounting to an average of 17.5 per cent of potential output over the period between 1997 and 2001. In addition to a moderate increase in direct foreign 
investment, foreign debt is projected to grow from US $\$ 217$ million in 1996 to US $\$ 431$ by the end of 2001 . The size of the foreign financing gap under the socially desirable growth path illustrates quite vividly the centrality of the foreign exchange constraint in general, and preferential market access in particular, on Fiji's ability to achieve a modest rate of growth in the medium term. Clearly, the challenge for Fiji's policymakers is to intensify export diversification efforts and to improve the government savings rate. The former requires, among other things, a set of coherent and consistent export promotion efforts directed at utilising Fiji's comparatively well-educated and skilled workforce and attracting foreign direct investment into joint ventures in international services. Such a strategy, focused as it is on higher value-added activities, might serve to increase the rate of capacity utilisation in the economy and increase the rate of growth of the economy. Export diversification efforts should, however, be accompanied by an improvement in government savings if a modest rate of growth is to be achieved in the short and medium term. Finally, it has been suggested in this chapter that in order to improve the efficiency of state intervention in the economy, and thus government savings, there may be a need to reduce the 'ethnicisation' of economic policy. Clearly, achieving a socially desirable growth path in Fiji in the medium term is a major challenge for the new government.

\section{Endnotes}

1. Neither the year of the coups, 1987, nor the immediate catch-up year of 1988 have been used in calculating the period averages in this chapter, in an effort to garner a better understanding of the relative economic performance of the Fiji economy under adjustment. It can be noted that making some alterations to the years included in the period averages does not shift the direction of change but rather only affects the magnitude of change, and only then to a small degree.

2. The following three subsections draw heavily on Akram-Lodhi (1996).

3. Less mathematically inclined readers may want to skip this section.

4. Output is here defined in somewhat non-standard fashion, reflecting the importance of intermediate imports in production for a developing country such as Fiji. 
5. Private savings $\left(s_{p}\right)$ were estimated as a residual from the Keynesian national income identity, which can be written in normalised form as:

$$
s_{p}=i_{p}+i_{g}-s_{g}+e-m-m_{k}-m_{z}-j^{*}
$$

where other terms are as they are defined in the text.

6. The growth-investment Equation 15 is obtained by substituting the total investment Equation 5 into the growth Equation 3 using the private investment Equation 7. The savings gap Equation 16 is obtained by substituting Equations 7 to 10 and 14 into Equation 3. Substituting Equations 12 and 13 into the foreign savings Equation 14 yields the foreign savings gap Equation 17. Finally, the fiscal gap Equation 18 is obtained by substituting Equations 9 and 10 into Equation 11, the public sector borrowing requirement.

7. Budgetary appropriations to public enterprises amounted to about 55 per cent of total public sector capital expenditure over the period 1985-90 (Elek, Hill and Tabor 1993: Table 2).

8. Our thanks to David Styan for directing us to Collier's work on ethnicity and economic performance. 
This text is taken from Confronting Fiji Futures, edited by A. Haroon Akram-Lodhi, published 2016 by ANU eView, The Australian National University, Canberra, Australia. 